\title{
Effects of Surfactants on Pectinase Treatment of Cotton/Chitosan Blends
}

\author{
Yu Sun Song • Hye Rim Kim • Wha Soon Song ${ }^{\dagger}$ \\ Dept. Clothing \& Textles, Sookmyung Women's University
}

Received November 6, 2009; Revised December 9, 2009; Accepted December 15, 2009

\section{면/키토산 혼방섬유의 펙티나제 처리시 계면활성제의 영향}

\author{
송유선 · 김혜림 · 송화순 \\ 숙명여자대학교 의류학과 \\ 접수일(2009년 11월 6일), 수정일(2009년 12월 9일), 게재확정일(2009년 12월 15일)
}

\begin{abstract}
This study examined the effect of surfactant pretreatment on the pectinase-treated cotton/chitosan blends by weight loss and properties such as water absorbency, dyeability, tensile strength, pilling property, and surface morphology. The weight loss of cotton/chitosan blends was $1.5 \%$ by the surfactant pretreatment/pectinase treatment. The water absorbency and dyeability of samples showed a significant improvement by the surfactant pretreatment/pectinase treatment. The tensile strength and pilling property of treated fabrics showed no change. The water absorbency and dyeability of pectinase treated samples improved with the pretreatment of the surfactant without damaging the fibers.
\end{abstract}

Key words: Pectinase, Surfactant pretreatment, Cotton/Chitosan blends, Water absorbency, Dyeability; 펙티나제, 계면활성제 전처리, 면/키토산 혼방섬유, 흡수속도, 염색성

\section{Introduction}

Concerns regarding health, energy, and the environment have stimulated the improvement of enzyme technology in the textile industry (Bielen \& Li, 2002). Enzymatic processing has been developed for natural fibers in wide-ranging operations, from cleaning preparations to finishing (Cavaco-Paulo \& Gubitz, 2003; Kirk et al., 2002; Tzanov et al., 2001). During enzymatic processing, surfactants are typical auxiliaries that enhance enzyme penetration, adsorption, and fiber swelling (Cavaco-Paulo \& Gubitz, 2003). When cotton is treated with enzymes, a surfactant should be included in the processing (Shamey \& Hussein, 2005; Tzanov et al., 2003).

Corresponding author

E-mail: doccubi@ sookmyung.ac.kr
Studies about surfactants during enzymatic treatment of cotton fibers have also been reported about the pretreatment using nonionic and anionic surfactants. Nonionic surfactant pretreatment of cotton fibers did not affect on the hydrolytic activity of cellulase and acid pectinase (Li \& Hardin, 1998). However, it was reported that pretreatment with nonionic surfactant helped improve the absorbency of cotton fibers treated with acid cellulase and pectinase treatment (Losonczi et al., 2004). The pretreatment with anionic surfactant was reported to facilitate the hydrolytic activity of alkaline protease on cotton fibers (Yoshimura et al., 2003). Most studies on the pretreatment with surfactants during enzymatic processing used cotton fibers as substrates. A few studies was subjected the cotton blends (Lee, 2007). Among various cotton blends, when enzymatic treatments are applied to 
cotton/chitosan blends, enzymes should hydrolyze cotton fibers without damaging chitosan fibers (Song et al., 2008). Chitosan fibers have a similar structure with cotton fibers and the effective hydrolases of cotton fibers can affect on chitosan fibers. In a previous study (Song et al., 2008) it was reported that pectinase treatment of cotton/chitosan blends was an effective method of removing non-cellulose in cotton without damaging chitosan fibers.

This study investigates the suitable surfactants for pretreatment to improve absorbency and dyeability of cotton/chitosan blends during pectinase treatment. One of nonionic surfactant and two of anionic surfactants are selected as the surfactants for this study. The weight loss and properties, such as water absorbency, dyeability, tensile strength, pilling property, and surface morphology, are examined to discern any inhibitory action of the surfactants on the hydrolytic activity of pectinase.

\section{Experimental}

\section{Materials}

The cotton/chitosan blends provided by Texan Medtech Co., Ltd. was used as the specimen for this study. $\langle$ Table 1$\rangle-\langle$ Table 2$\rangle$ shows the characteristics of the fabric and enzyme. To maintain a constant $\mathrm{pH}$ during pectinase treatment, the mixture of sodium carbonate $\left(\mathrm{Na}_{2} \mathrm{CO}_{3}\right.$, Duksan Pure Chemicals, South Korea) and acetic acid $\left(\mathrm{CH}_{3} \mathrm{COOH}\right.$, Duksan Pure Chemicals, South Korea) were used as buffer solution according to the manual of the manufacturer. The $\mathrm{pH}$ was adjusted to each $\mathrm{pH}$ by using $1 \mathrm{M}$ acetic acid or $0.1 \mathrm{M}$ sodium carbonate. Triton X-100 (Sigma Chemicals, USA) as a nonionic surfactant, laurylbenzene sulfonic-acid sodium salt (LAS, $\mathrm{C}_{12} \mathrm{H}_{25} \mathrm{C}_{6} \mathrm{H}_{4} \mathrm{SO}_{3} \mathrm{Na}$, Junsei Chemicals, Japan) and the anionic surfactant, sodium dodecyl sulfate (SDS, $\mathrm{CH}_{3}\left(\mathrm{CH}_{2}\right) 10 \mathrm{CH}_{2} \mathrm{OSO}_{3} \mathrm{Na}$, Junsei Chemicals, Japan) as anionic surfactants were used for pretreatments. Apollocion Red H-E3B (C.I. Reactive Red 120, Taiheung Corporation, South Korea) was used to dye the treated fabrics. Sodium sulfate ( $\mathrm{Na}_{2} \mathrm{SO}_{4}$, Samchun Pure Chemical Co., South Korea) and sodium carbonate were used as additives.

All chemicals were used without further purification.

\section{Methods}

\section{1) Surfactant Pretreatment}

Fabrics were soaked at a $25: 1$ liquid ratio at $20^{\circ} \mathrm{C}$ temperature for 10 minutes in each surfactant solution. Samples were squeezed evenly and controlled pickup rate of $100 \%$, then dryed at room temperature. Surfactant pretreated fabrics were treated with pectinase without rinsing.

\section{2) Pectinase Treatment}

Pectinase treatment was carried out by the optimum condition reported in the previous report (Song et al., 2008). The buffer solution was prepared by mixing sodium carbonate and acetic acid, and the $\mathrm{pH}$ of the buffer solution was controlled using $0.1 \mathrm{M}$

Table 1. Fabric characteristics

\begin{tabular}{|c|c|c|c|c|c|c|}
\hline \multirow{2}{*}{ Fiber $(\%)$} & \multirow{2}{*}{ Knit type } & \multirow{2}{*}{$\begin{array}{l}\text { Yarn count } \\
\text { ('s) }\end{array}$} & \multicolumn{2}{|c|}{ Density (inch) } & \multirow{2}{*}{$\begin{array}{l}\text { Weight } \\
\left(\mathrm{g} / \mathrm{m}^{2}\right)\end{array}$} & \multirow{2}{*}{$\begin{array}{c}\text { Thickness } \\
(\mathrm{mm})\end{array}$} \\
\hline & & & wale & course & & \\
\hline cotton $97 /$ chitosan 3 & single jersey & $40 / 2$ & 28 & 28 & $150 \pm 5$ & 0.60 \\
\hline
\end{tabular}

Table 2. Enzyme properties

\begin{tabular}{c|c|c|c|c}
\hline \hline Enzymes & Source & Activity & Form & Manufacturer \\
\hline $\begin{array}{c}\text { Scourzyme } \\
(\text { EC } 4.2 .2 .2)\end{array}$ & Bacillus & 375APSU/g** & liquid & Novozymes \\
\hline
\end{tabular}

*Scourzyme ${ }^{\circledR} \mathrm{L}$ is an alkaline pectate lyase from Bacillus produced by submerged formation of a genetically modified Bacillus microorganism.

**APSU: Alkaline Pectinase Standard Units; one unit of enzyme activity was defined as the amount of enzyme that catalysed the formation of one ìmol unsaturated uronide product $\cdot \min ^{-1}$. 
sodium carbonate and $1 \mathrm{M}$ acetic acid. Cotton/chitosan blends were treated with pectinase at $\mathrm{pH} 8.0$, $55^{\circ} \mathrm{C}$, for 50 minutes using a liquor ratio of $25: 1$. The enzyme inactivation was performed at $90^{\circ} \mathrm{C}$ for 10 minutes. Fabrics are rinsed with water and dried at room temperature (Song et al., 2008).

\section{3) Weight Loss}

Weight loss of the treated fabrics was measured using the dry weight and was calculated with the following equation:

$$
\text { Weight loss }(\%)=\frac{\mathrm{W}_{1}-\mathrm{W}_{2}}{\mathrm{~W}_{1}} \times 100
$$

$\mathrm{W}_{1}$ : Dry weight of the fabric before treatment,

$\mathrm{W}_{2}$ : Dry weight of the fabric after treatment.

\section{4) Measurement of the Properties}

Water absorbency of the treated fabrics was measured according to AATCC 79-1992.

Dyeability of fabrics was measured by the absorbance of the dyeing solution using UV-VIS spectrophotometer (UV-1201, Shimaz, Japan). The tensile strength and pilling property were measured according to KS K 0520 and KS K 0503, respectively. The surface morphology of the treated fabrics was analyzed using a scanning electron microscope (SEM, Jeol JSM820, Japan).

\section{Results and Discussion}

$<$ Fig. 1> shows the weight loss of surfactant pretreated/pectinase treated $(\mathrm{P} / \mathrm{T})$ fabrics by different surfactant concentrations. As shown in <Fig. 1>, there was no significant difference in weight loss by the concentration of surfactant when the $\mathrm{pHs}$, treatment temperatures, enzyme concentrations, and treatment durations were identical.

Compared to pectinase treated fabrics (about 1.4\%), the weight loss of $\mathrm{P} / \mathrm{T}$ fabrics increased slightly to $1.5 \%$. Even though the pectinase removed the wax of cotton fibers effectively (Song et al., 2008), the surfactant pretreatment helped emulsify and remove the wax without residue (Datyner, 1983); the weight loss improved slightly.

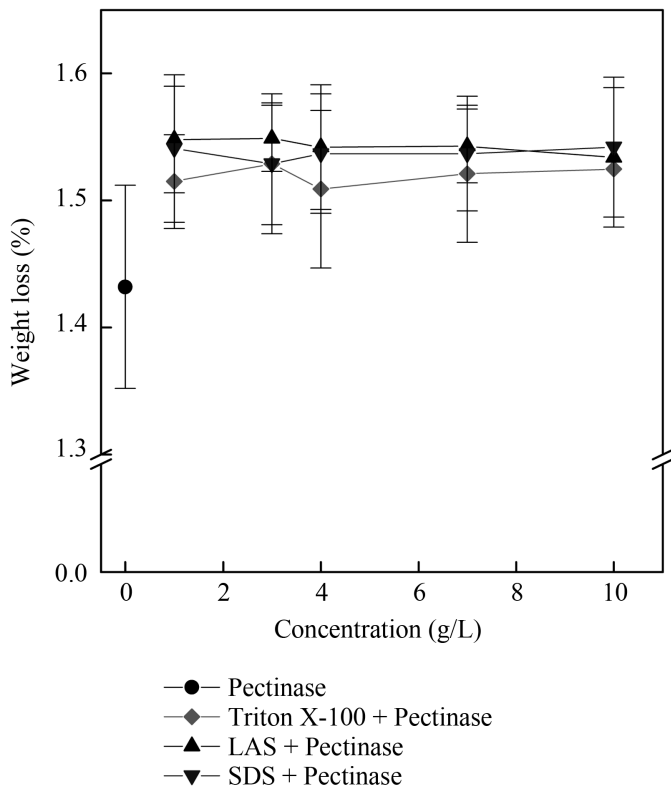

Fig. 1. Effect of surfactnat concentration on the weight loss of pectinase-treated cotton/chitosan blends.

In terms of surfactants, the weight loss of P/T fabrics with anionic surfactant showed a 1.1-fold increase compared to nonionic pretreated fabrics. Anionic surfactants were reported to inhibit the hydrolytic activity of enzymes depending on their structure (CavacoPaulo \& Gubitz, 2003). However, anionic surfactants, LAS and SDS, did not affect on pectinase treatment and the better wax-emulsifying capacity compared to nonionic surfactant (Milton, 1989) was maintained during pectinase treatment. In addition, the narrowed error range of the weight loss by surfactants pretreatment showed that the surfactant pretreatment helped the hydrolytic activity of pectinase remains stable.

<Fig. 2> shows the water absorbency of the P/T fabrics by different surfactant concentrations. There was no significant difference in water absorbency by the surfactant type and concentration. The time of water absorbency of untreated fabrics was above 900s. The time of water absorbency of pectinase treated and P/T fabrics showed 536s and 178-188s, respectively. The surfactant pretreatment helped improve water absorbency because surfactants emulsified and removed the wax without residue (Datyner, 


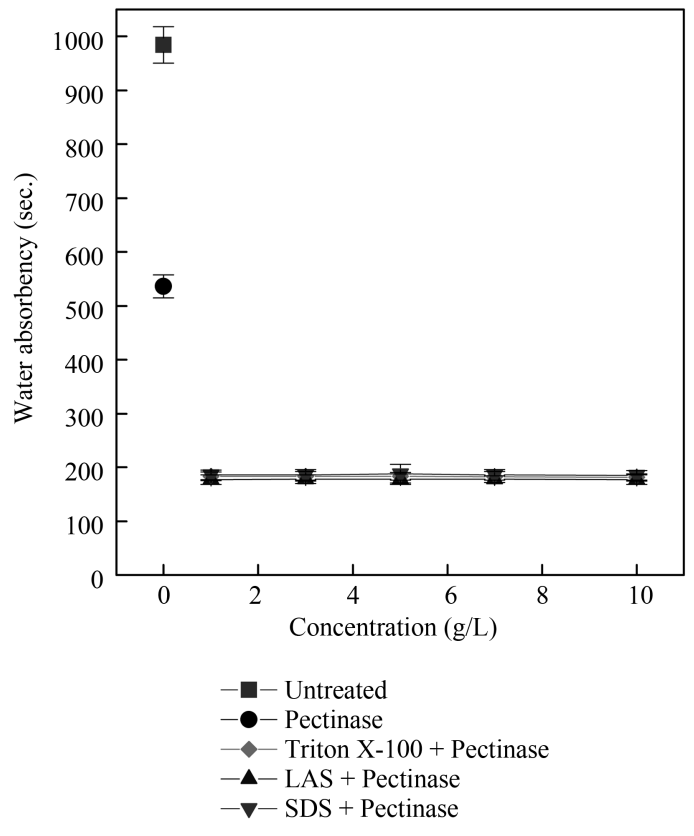

Fig. 2. Effect of surfactnat concentration on the water absorbancy of pectinase-treated cotton/chitosan blends.

1983). In addition to the wax-emulsifying capacity, the surfactant could change the surface of fabrics to hydrophilicity (Kim, 2001; Kim \& Song, 2008). The water absorbency of fabrics treated with both surfactants and pectinase improved.

The concentration of the surfactant during pretreatment did not affect weight loss and water absorbency. The concentration of the surfactant was set at $1 \mathrm{~g} / \mathrm{l}$.

<Fig. 3> shows the dyeability of the pectinase treated and P/T fabrics. The dye uptake of cotton and chitosan shows a significant difference, so cotton/ chitosan blends are dyed as melange. The dyeability was measured by the absorbance of dyeing solution not by K/S values.

The dyeability of the cotton/chitosan blends by pectinase treatment improved 1.2 times, compared to the untreated samples. Compared to the pectinase treated fabrics, the dyeability of the nonionic pretreated fabrics increased 1.4 times. In addition, the dyeability of the LAS pretreated fabrics and SDS pretreated fabrics improved 1.6 times and 1.3 times,

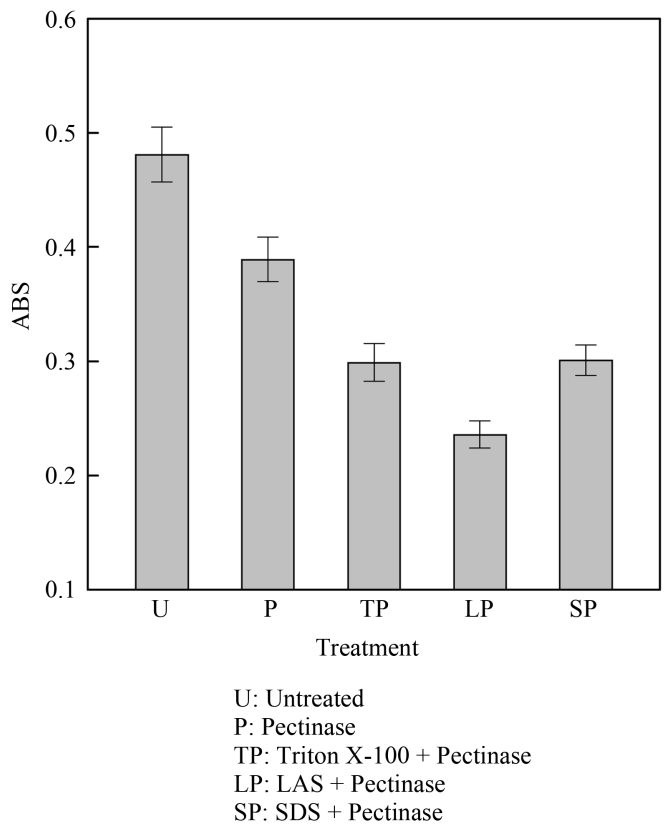

Fig. 3. Effect of surfactnat on the ABS of pectinasetreated cotton/chitosan blends.

respectively, compared to the pectinase treated fabrics. The improvements of dyeability of the pretreated fabrics were caused by the removal of the pectin and wax on the fiber in addition to changing surface to hydrophilicity. The dyeability of the cotton/chitosan blends can be improved by the surfactant pretreatment.

$<$ Fig. 4> shows the tensile strength and pilling property of the $\mathrm{P} / \mathrm{T}$ fabrics. Both surfactant type and pretreatment did not influence the tensile strength and pilling properties of the cotton/chitosan blends. It is concluded that the surfactants pretreatment helped remove wax and change fabric surface to hydrophilicity without damaging the fabrics.

$<$ Fig. 5> shows the surface morphology of the cotton/chitosan blends treated with pectinase after LAS pretreatment. The untreated fabrics showed many impurities on the fabric surface. The impurities of the treated fabrics were removed through the pectinase treatment. Cotton/chitosan fabrics pretreated with LAS showed to remove impurities and cover a thin layer. The effective wax-emulsifying capacity of LAS helped 

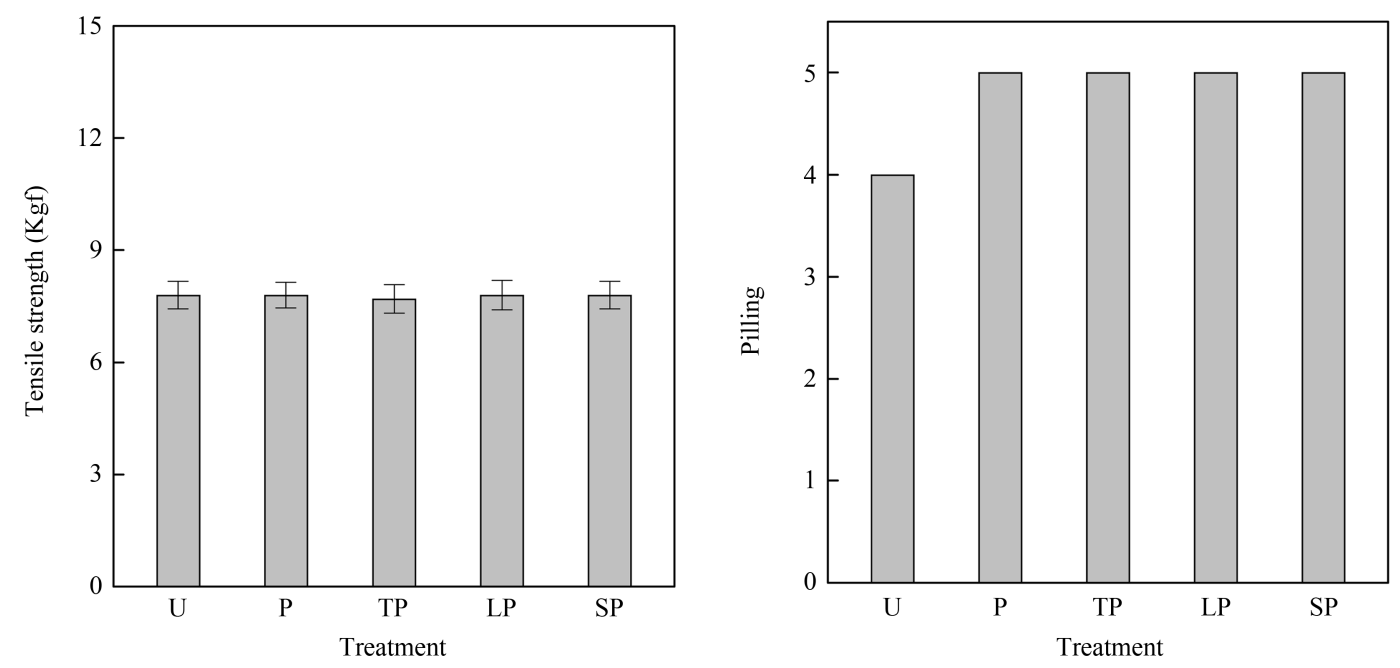

U: Untreated P: Pectinase TP: Triton X-100 + pectinase

LP: LAS + pectinase

SP: SDS + pectinase

Fig. 4. Tensile strength and pilling of pectinase-treated cotton/chitosan blends.

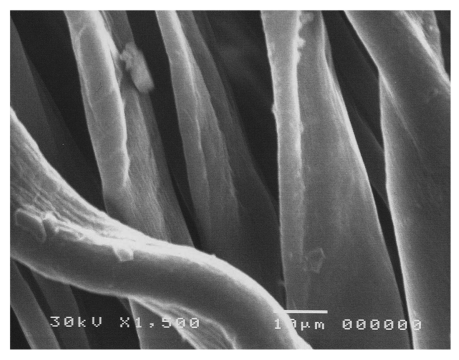

untreated

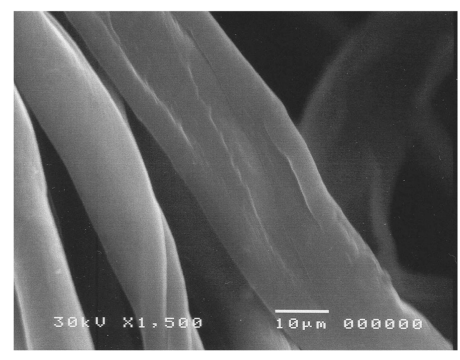

pectinase-treated

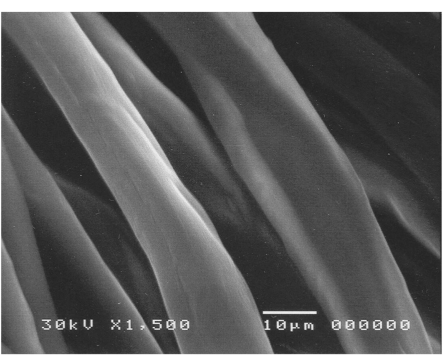

LAS + pectinase-treated

Fig. 5. SEM micrographs of pectinase-treated cotton/chitosan blends.

thoroughly remove impurities on the fabrics, as proven by the weight loss measurement. In addition, the thin layer that could be concluded as the LAS layer, changed the surface to hydrophilicity (Park \& Kim, 1993), which influenced water absorbency.

\section{Conclusions}

In this study, the effect of surfactant pretreatment on the pectinase-treated cotton/chitosan blends were examined by weight loss and properties, such as water absorbency, dyeability, tensile strength, pilling property, and surface morphology. Compared to fabrics, the weight loss of the $\mathrm{P} / \mathrm{T}$ fabrics increased slightly to $1.5 \%$. The time of water absorbency of pectinase and P/T fabrics showed 536s and 178188 s, respectively. The dyeability of the P/T fabrics improved compared to the untreated and the pectinase treatment. Both surfactant type and pretreatment did not influence the tensile strength and the pilling properties of the cotton/chitosan blends. The surfactant pretreatment was shown to help improve water absorbency and the dyeability of the cotton/chitosan blends.

\section{References}

Bielen, J. B. V., \& Li, Z. (2002). Enzyme technology: An overview. Current opinion in biotechnology, 13(4), 338344. 
Cavaco-Paulo, A., \& Gubitz, G. M. (2003). Textile processing with enzymes. Boca Raton: CRC press.

Datyner, A. (1983). Surfactants in textile processing. New York: Marcel Dekker Inc.

Kim, C. H. (2001). Effect of nonionic surfactant solutions on wetting and absorbancy of cotton fabrics. Clothing and Textiles Research Journal, 25(8), 1444-1452.

Kim, H. R., \& Song, W. S. (2008). Effect of triton X-100 and calcium chloride on the porcine pancreas lipase treatment of PET fabrics. Journal of the Korean Society of Clothing and Textiles, 32(6), 911-917.

Kirk, O., Borchert, T. V., \& Fuglsang, C. C. (2002). Industrial enzyme applications. Current opinion in biotechnology, 13(4), 345-351.

Lee, S. H. (2007). Enzymatic modification of cotton/polyester blend fabrics. Unpublished master's dissertation, Sookmyung Women's University, Seoul.

Li, Y., \& Hardin, I. R. (1998). Enzymatic scouring of cotton - surfactants, agitation and selection of enzymes. Textile chemist and colorist, 30(9), 23-29.

Losonczi, A., Csiszar, E., \& Szakacs, G. (2004). Bleachability and dyeing properties of biopretreated and conventionally scoured cotton fabrics. Textile Research Journal,
74(6), 501-508.

Milton, J. R. (1989). Surfactants and interfacial phenomena. New York: A Wiley-Intersince Publication.

Park, S. K., \& Kim, S. R. (1993). A study on the adsorption of anionic surfactant by various textile fibers and rinsing efficiency in washing process. Clothing and Textiles Research Journal, 17(1), 129-136.

Shamey, R., \& Hussein, T. (2005). Critical solutions in the dyeing of cotton textile materials. The Textile Progress, 37(1/2), 17-19.

Song, Y. S., Song, W. S., Lee, B. H., \& Kim, H. R. (2008). Scouring of cotton/chitosan blend fabrics by pectinase. Textile Science and Engineering, 45(4), 199-207.

Tzanov, T., Andreaus, J., Guebitz, G., \& Cavaco-Paulo, A. (2003). Protein interactions in enzymatic processes in textiles. Electronic Journal of Biotechnology, 6(3), 146154.

Tzanov, T., Calafess, M., Guebitz, G. M., \& Cavaco-Paulo, A. (2001). Bio-preparation of cotton fabrics. Enzyme and Microbial Technology, 29, 357-362.

Yoshimura, Y., Ohe, T., Abe, I., \& Sawada, K. (2003). Promoting effect of surfactants on enzyme treatment of wool. Sen'I Gakkaishi, 59(1), 35-39.

\section{요 약}

본 연구는 면/키토산 혼방섬유에 펙티나제 처리시 계면활성제 전처리에 따른 영향을 알아보기 위해 감 량률, 흡수속도, 염색성, 인장강도, 필링성 및 표면형태를 살펴보았다. 계면활성제 전처리 후 펙티나제 처 리시 감량률은 약 $1.5 \%$ 였으며, 흡수속도는 계면활성제 전처리에 의해 크게 향상되었다. 인장강도와 필링 성 측정결과 계면활성제 전처리에 따른 변화는 나타나지 않았다. 표면관찰 결과, LAS 전처리 후 펙티나 제 처리한 면/키토산 혼방섬유의 표면에 계면활성제가 흡착됨을 확인하였다. 이상의 결과를 통해, 면/키 토산 혼방섬유의 펙티나제 처리시 계면활성제 전처리는 면/키토산 혼방섬유의 흡수성과 염색성 향상에 효과적임을 확인하였다. 